\title{
The Eradication of Poliomyelitis in Spain: Projects, Obstacles, Achievements, Realities
}

\author{
Rosa Ballester, María-Isabel Porras and María-José Báguena
}

\section{Introduction}

he main aim of our paper is to provide a historical approach to the complex process undertaken in Spain to achieve the official WHO certificate of

1 polio eradication in 2002, within the framework of the initiatives launched in the WHO European Region. At the time of the first meeting of the European Regional Commission for the Certification of Poliomyelitis Eradication in 1996, the epidemiological situation and levels of vaccination cover (over 90\%) enabled Spain, like other countries, to ensure compliance with the conditions set by the World Health Organization. This showed that the country, at the end of the twentieth century, had achieved high public health standards, which is remarkable if one considers that the country had suffered forty years of dictatorship and that the previous health care system had important failings. The changes that allowed Spain to join those European countries that obtained eradication certification are to be found within the framework of the deep social, political, economic and cultural transformation behind this process. In order to make a more complete assessment, we seek to analyse the set of projects designed, the obstacles encountered in their practical implementation and the final outcomes.

Our main sources are the official WHO publications - technical reports, the Bulletin of the WHO and other documents- as well as Proceedings of the International Poliomyelitis Conferences (1948-1960) and the European Association against Poliomyelitis Symposia (1953-1969) ${ }^{1}$. In addition we have used printed sources and other kinds of grey literature (reports and other unpublished

1 Information about both scientific meetings and The European Association against Poliomyelitis figures in Maria-Isabel Porras; María-José Báguena; Rosa Ballester, "Spain and the scientific conferences on polio, 1940s-1960s", Dynamis, 30 (2010), 91-118; María-Isabel Porras; Rosa Ballester; María-JoséBáguena; Jaime de las Heras, "La Asociación Europea contra la Poliomielitis y los programas europeos de vacunación”, Dynamis, 32(2) (2012), 287-310. 
documents) from the archives of the Carlos III Institute of Health', as well as the Spanish Weekly Epidemiological Bulletin and a selection of daily newspapers such as $A B C$, La Vanguardia, and El Pais in order to analyse how an ambitious global health initiative was implemented at a local level. Finally, we have also used the oral testimony of a key figure, the president of the National Commission for the Certification of the Eradication of Poliomyelitis, Ferran Martínez-Navarro.

The programme to eradicate polio worldwide must be considered in the broader context of the eradication of infectious diseases of which, the first and most successful programme was the global eradication of smallpox led by the WHO between 1967 and $1978^{4}$. Indeed, this highlight is one of the great success stories of twentieth-century public health medicine and a fundamental stimulus not only for contemporary debates regarding the possible eradication of other infectious diseases $^{5}$, but also for the launch, a decade later, of the Global Polio Eradication Initiative ${ }^{6}$. Most doctors and public health workers ${ }^{7}$ were aware of the historical significance of the process and described the need to clarify concepts in this new area that appeared to be opening in the history of medicine and public health. Previously the term "eradication" had been used inaccurately to mean the disappearance of a particular infectious disease in a particular country. Thus, the term "global eradication" was coined in the 1980s to describe the achievement of a

2 As we will show, this Institute had a prominent role in the final control of the poliomyelitis in Spain and in the development of the Spanish epidemiology and virology through the National School of Health and the Virology Institute of Majadahonda (Madrid, Spain).

$3 A B C(1903-)$ is a monarchist daily newspaper, representing the national generalinterest press, and has been widely-circulated for many years. La Vanguardia (1881-) is a Catalan general-interest daily newspaper, a very good example of the commercial press founded at the end of the nineteenth century; it has succeeded in maintaining its important position to the present day. El Pais (1976-) is a national daily newspaper that played an important role among the media of the Spanish Transition after the Dictatorship of Franco.Although little information was forthcoming from these sources, we still consider them essential for a comprehensive analysis, as in the case of the Boletin Epidemiológico Semanal (Spanish Weekly Epidemiological Bulletin). The review of the six years between 1996 and 2002 of the latter has enabled us to recover only 4 articles related to the polio eradication process in Spain and 2 on the situation in the World.

4 Hervé Bazin, The Eradication of Smallpox(San Diego, 2000); Frank Fenner, "The Eradication of infectious diseases", South African Medical Journal, 66 (1988), 35-39; Frank Fenner; Donald A. Henderson; Isao Arita et al., Smallpox and its Eradication (Geneva, 1988); Donald Henderson, "Smallpox eradication: a victory against the Cold War", World Health Forum, 19 (1998), 115-121.

5 Dorothy M. Hortsmann, "Preface", Reviews of Infectious Diseases, 6 (Suppl. 2) (1984), S301.

6 Matthew R. Smallman-Raynor; Andrew D. Cliff; Barry Trevelyan; Clive Nettleton; Sam Sneddon, A world geography. Poliomyelitis. Emergence to eradication (Oxford, 2006), p. 564.

7 James Chin, "Can paralytic poliomyelitis be eliminated?", Reviews of Infectious Diseases, 6 (Suppl. 2) (1984), S581-585. 
level of control of infectious diseases characterized by the complete and permanent cessation, worldwide, of the natural transmission of infectious agents. ${ }^{8}$

Global eradication campaigns were launched during the term of Marcolino Candau (1911-1983) as Director General of the WHO, but mostly it was his successor Halfdan Mahler (1923-), Director General three times between 1973 and 1988, who inspired the process at a time when the WHO was entering a phase of renewal. In this period, the organization emphasized not only technical aspects (insisting on the rigorous application of epidemiological methods with a strong statistical base) but also a social approach in which the participation of community in health issues was fundamental. These ideas were explicitly set out in the paradigmatic Declaration of Alma Ata in 1978 and the GOBI strategy (Growth monitoring, Oral rehydration techniques, Breast feeding, Immunization) which included universal vaccination against the major preventable diseases. The new proposals were different from the previous "vertical" ones. In this way, the most important change was that the eradication and immunization programmes ceased to operate according to a rigid design applied "from above" with low levels of participation of the people involved in vaccination campaigns?.

The authors who have studied the history of the approaches adopted by WHO at different stages of the organization ${ }^{10}$ have stressed that, in order to achieve these objectives, it was necessary to take into account such local circumstances as the propaganda strategies of vaccination programmes which were adapted to the socioeconomic structures and specific cultures where the activities were to be carried out. This was fundamental in understanding both the achievements and the failures of those programmes according to local circumstances.

\section{Polio as a Target of Worldwide Eradication}

The selection of polio as a second candidate disease within the eradication project was taken in 1988 as a part of the conclusions of the $41^{\text {st }}$ World Health Assembly. The formal process for the eradication of polio was established on the basis of the experience with smallpox. Independent groups of experts were appointed to

8 Frank Fenner, "The eradication of infectious diseases", South Africa Medical Journal, 66 (suppl.) (1986), 35-39.

9 Marcos Cueto, The value of health. A history of the Pan American Health Organization (Washington, 2007).

10 World Health Organization, The first ten years of the World Health Organization (Geneva, 1958); World Health Organization, The second ten years of the World Health Organization from 1958 to 1967 (Geneva, 1968); World Health Organization, The Third ten years of the World Health Organization, 1968-1977 (Geneva, 2008); World Health Organization, The Fourth ten years of the World Health Organization, 1978-1987 (Geneva, 2011). 
international, regional and national level commissions in order to establish a set of criteria and conduct properly the certification process ${ }^{11}$.

However, prior to the Assembly, the question of eliminating polio worldwide had also been raised at the International Poliomyelitis Conferences ${ }^{12}$. At the III conference (1954), John J. Paul, one of the most outstanding figures in polio research, presented a paper entitled "Future Prospects", which was included in a wider session on "Trends in Poliomyelitis". Given the hopeful early results achieved with polio vaccines, he was encouraged by the possibility of preventing the disease and, perhaps even of eliminating it. He insisted that this goal could not be accomplished by a single laboratory or a single country, but would require a joint effort $^{13}$.

In similar terms, at the IV Conference (1957), the honorary president, the American Basil O'Connor, head of the National Foundation for Infantile Paralysis, was commissioned to draw up the conclusions. In this document, he also referred to the possibility of eliminating polio:

Since I know that you feel, as we of the United States feel, that the elimination of paralytic polio in one country only is not the goal that is sought, I repeat that there is a likelihood that we will have eliminated paralytic polio in the United States by 1958 . That is not the goal of any science and should not be; that is not the goal of the International Congress. The goal should be the elimination of paralytic polio throughout the world ${ }^{14}$.

Two years later, in 1959, when polio vaccination campaigns had been implemented in several countries, Frank L. Horsfall, president of the scientific committee of the V Congress, was given the task of summarizing all those papers presented. In this case, although he also showed the advances in the control of polio, he did not mention 'eradication' but rather displayed a hopeful but still cautious attitude:

It seems no longer necessary to bolster optimism with uncritical hope. Means for the control of poliomyelitis appear to be at hand. What remains is to learn more of their vagaries and the best ways in which to use them. Once again, then, man has

11 Joseph Smith; Rose Leke; Anthony Adams; Rudolph H. Tangermann, "Certification of polio eradication: process and lessons learned", Bulletin World Health Organization, 82(1) (2004), 24-29.

12 María-Isabel Porras; María-José Báguena; Rosa Ballester, "Spain and the scientific conferences on polio, 1940s-1960s", Dynamis, 30 (2010), 91-118.

13 Poliomyelitis, Papers and Discussions presented at the Third International Poliomyelitis Conference (Philadelphia, 1955), p. 422.

14 Poliomyelitis, Papers and Discussions presented at the Fourth International Poliomyelitis Conference (Philadelphia, 1958), p. 665. 
demonstrated his almost limitless capacity to manage hazards in his own environment ${ }^{15}$.

The European Association against Poliomyelitis, which was set up in 1951 in Brussels, concluded its IV Symposium of 1956in similar terms considering that there was still necessary hardworking -both technically and theoretically- before getting the total elimination of the polio ${ }^{16}$. However, five years later, when the live vaccine was disposable, the eradication of the disease seemed to be possible:

It is thus argued that vaccination with the live vaccine, if practised on a wide scale... will not only bring about the complete eradication of poliomyelitis but also eliminate the causative viruses ${ }^{17}$.

The choice of poliomyelitis for global eradication was favoured by a series of biological circumstances such as the fact that poliovirus is transmitted only by infectious humans or their waste and the vector plays only a very limited role in contagion; the survival of poliovirus in the environment is finite; humans are the only reservoir of poliovirus and the oral vaccine interrupts poliovirus transmission. In addition to these biological circumstances, other fundamental factors included the social, economic, cultural and political perspectives of the problem, above all in the experience acquired in many countries through the mass vaccination campaigns ${ }^{18}$.An article published in the Bulletin of the WHO, one year before the official recognition by the General Assembly, showed clearly that "global eradication of poliomyelitis is inevitable: the only question is whether we will accomplish it or pass on the needed action to our successors" ${ }^{\prime \prime}$. The possible impediments to eradication included the necessity to generate political and social will but it was considered "that with intensified effort and increased international collaboration, global eradication could be achieved as early as 1995 "20.

Smallmann-Raynor et al. have stressed the role played by a global polio partnership comprising the WHO, Rotary International, Centers for Disease

15 Poliomyelitis, Papers and Discussions presented at the Fifth International Poliomyelitis Conference (Philadelphia, 1961), p. 426.

16 Association Européenne contre la Poliomyélite, IV Symposium, Bologna, 20-22 September1956 (Bruxelles, 1957), p. 44.

17 Association Européenne contre la Poliomyélite, VII Symposium, Oxford, 17-20 September 1961 (Bruxelles, 1962), p. 155.

18 Ciro A. de Quadros, "The whole is greater: How polio was eradicated from the Western Hemisphere". In: Daniel Perlman; Ananya Roy (ed.), The Practice of International Health. A case-based orientation (New York, 2009), pp. 54-69, p. 54-59.

19 Alan R. Hinman; William H. Foege; Ciro A. de Quadros; Peter A. Patriarca; Walter A. Orenstein; Edward W. Brink, "The case for global eradication of poliomyelitis", Bulletin of the World Health Organization, 65 (1987), 839; cited by Smallmann-Raynor et al. op cit, p. 570.

20 Alan R. Hinman, op. cit, p. 835.cited by Smallmann-Raynor et al. op cit, p. 570. 
Control (CDC) and UNICEF ${ }^{21}$. These institutions were, in turn, increasingly supported by a global network of humanitarian organizations, international agencies and private corporations ${ }^{22}$. Indeed, the social movement which developed around polio, unlike the case with other diseases, encouraged the raising of funds for other international health problems ${ }^{23}$.

In 1989 a Plan for global polio eradication by the year 2000 was drafted and a series of international meetings was held. The global eradication strategies pioneered by the Pan American Health Organization (PAHO) included high routine immunization cover, national immunization days (NIDs), acute flaccid paralysis surveillance and intensive "mopping-up" immunization campaigns used to interrupt the final chains of poliovirus transmission through vaccine administration on a house-to-house basis ${ }^{24}$.

Ten years after the launch of the eradication plan, the largest initiative ever undertaken, two international meetings in Dahlen (1997) and Atlanta (1998), were held to discuss and evaluate the eradication of the disease as a public health strategy. At these meetings, taking polio as an analysis model, various issues were discussed, such as whether the human and financial costs of these initiatives justified the concentration required to eradicate specific diseases. Three core questions were analysed:

1. Why eradicate polio (costs and benefits)?

2. Why is eradication technically feasible (biological determinants of eradicability)?

3. Why is this process socially and politically feasible? ${ }^{25}$

The responses were all positive. With regard to the first question, the arguments used included the magnitude of the humanitarian benefits, the economic costs of this type of disability, and the fact that vaccination campaigns had led also to improvements in the health services. On the second question, it was argued that oral disease vaccine was an effective weapon and that the implementation based on the National Immunization Days strategy had interrupted poliovirus transmission even in areas with low routine immunization cover. The availability and safety of

21 Matthew R. Smallmann-Raynor, op. cit, pp. 571-572.

22 The Melinda and Bill Gates Foundation also joined the cause in 2000.

23 Theodore M. Brown, Marcos Cueto, Elisabeth Fee, Historia, salud y globalización. (Lima, 2013), p. 98-99.

24 Miguel Mosquera, Natalia Barón, Rosa Ballester, "El camino hacia la erradicación de la poliomielitis a través de la Organización Panamericana de la Salud", Rev. Panam. Salud pública, 36 (3) (2014), 185-192.

25 R. Bruce Aylward; Harry F. Hull; Stephen L. Cochi et al., "Disease eradication as a public health strategy: a case study of poliomyelitis eradication", Bulletin of the World Health Organization, 78(3) (2000), 285-297. 
polio vaccines were much improved with the introduction of culture in continuous cell lines (Vero cells) by the Mérieux Institute of Lyon ${ }^{26}$. Furthermore, it had been found that culturing viruses from stool samples from cases of acute flaccid paralysis was a sensitive and specific tool for diagnosis.

The answer to the third question was more complicated because, unlike the objectivity and universality of the arguments used in the previous two, the issue depended on local circumstances. The development and maintenance of a social and political commitment were considered essential for this feasibility from an operational point of view. Furthermore, the implementation of this commitment made it necessary to test the eradication strategy in a large geographical area (the example given was that of the Region of the Americas, the first to receive the official certificate in 1994).

In short, eradication would help to combat inequity and would favour social justice. If these principles were supported by humanitarian, economic and other benefits, there would be significant reasons to consider the eradication of poliomyelitis as a valuable public health strategy.

\section{The European Programme for the Eradication of Poliomyelitis}

The general principles began to take shape in the different regions into which the WHO was divided. As far as the European Region was concerned ${ }^{27}$, the seventh meeting of the European Group of the Expanded Programme on Immunization ${ }^{28}$ reviewed the general and specific aims of the programme and determined that by 2000 , or as soon as possible, indigenous poliomyelitis, caused by the wild-type poliovirus, should be eradicated from the Region.

The Global Commission for the Certification of the Eradication of Poliomyelitis (GCC), was set up in 1995 to supervise, at a global level, activities carried out in this field, including such conceptual aspects as the definition itself of eradication adapted to the case of polio:

26 Bernard Seytre; Mary Shaffer, Histoire de la poliomyélite (Paris, 2004), pp. 103-110; Samuel L. Katz; Catherine M. Wilfert; Frederick C. Robbins, "The Role of Tissue Culture in Vaccine Development", in S.A. Plotkin, ed., History of Vaccine Development (New York, 2011), pp. 145-148; Florian Horaud, "Viral Vaccines and Cell Substrate: A 'Historical' Debate”, in S.A. Plotkin, ed., History of Vaccine Development (New York, 2011), pp. 151-154.

27 Aurora Limia-Sánchez, "La erradicación de la poliomielitis en la Región Europea de la Organización Mundial de la Salud”, Revista Española de Salud pública, 87 (2013), 507-516.

28 The Expanded Programme on Immunization (EPI), was set up in 1979, under the auspices of the WHO and the PAHO, in order to achieve universal vaccination designed to reduce mortality and morbidity through immune prevention and to control, eliminate and eradicate such diseases. 
The Worldwide Eradication of Poliomyelitis means the eradication of all wild-type viruses. The existence of clinical cases of poliomyelitis caused by other enteroviruses, including attenuated viruses from anti-polio vaccines, does not invalidate the eradication of wild-type polioviruses ${ }^{29}$.

A second fundamental aspect was to endorse global criteria for the certification of an area as free from polio. There were two main types of criteria:

- Absence of wild-type virus -isolated from clinical cases of flaccid paralysis suspected of having being caused by polio, both from healthy individuals and environmental samples- for a minimum period of three years within a system of proper epidemiological vigilance.

- The effective control of all stocks of polio virus in accredited laboratories ${ }^{30}$. The Global Commission for the Certification of the Eradication of Poliomyelitis (GCC) gave rise to the Regional Certification Commissions (RCCs) which, in the case of the European Region, began work in 1996. The Commission, which sought to adapt the general norms to the European reality, met periodically and produced a series of reports $^{31}$. In order to coordinate national strategies and in the interests of greater effectiveness, the presidents of the national committees for the certification of eradication of the disease also held regular meetings from 1997 onwards ${ }^{32}$. As had previously occurred in other regions (Americas 1994; Western Pacific 2000), the official certification in the European Region took place at a solemn ceremony on 21 June 2002 at the European headquarters of the WHO in Copenhagen ${ }^{33}$. The last case of wild-type polio in the 55 countries of the Region had been reported in Turkey in November 1998.

The main Spanish newspapers reported the achievement: $A B C$ of 22 June 2002, under the headline "Polio officially eradicated from Europe after years of mass vaccinations" (p. 60), and the Barcelona newspaper La Vanguardia, six months after certification, used the event to introduce the subject of polio in the World and the work carried out to date. Under the heading "Victory over polio" and the subheading "Five years of solidarity", the Sunday magazine of 22nd December 2002 described activities in India, Sudan, Somalia and the Republic of the Congo in

29 Report of the 1st meeting of the Global Commission for the certification of the Eradication of Poliomyelitis (Geneva, 1995).WU WHO/EPI/GEN95.6 document WHO.

30 Ibidem.

31 World Health Organization, Report of the first meeting of the European Regional Commission for the certification of polio eradication. Paris, 7-8 march 1996 (Geneva, 1996).

32 World Health Organization, Certification of Poliomyelitis Eradication in the European Region. Report on a WHO Meeting. Vienna, 16-17 December 1997 (Copenhagen, 1998).

33 "Certification of poliomyelitis eradication -European Region", MMWR Morbidity and Mortality Weekly Report, 51 (2002), 572-574. 
order to encourage funding for the work that remained to be done (La Vanguardia, 22-12-2002). The dailies recalled the eradication of the disease in the region of the Americas in 1994 and insisted on the importance of the WHO target of worldwide eradication by 2005 . $A B C$ used the good news to remind readers that the last outbreaks in Spain had occurred in Andalucía in the years 1987-88 and that thereafter the few cases reported in the 1990s had been vaccine-linked (p. 60). Just over a month later and under the headline "Health Ministry estimates 36,000 possible cases of post-polio syndrome", El Pais reported on another important problem arising from the polio epidemics which had occurred during the Francoist period and which to that date had failed to receive the response it required (El Pais, 30-7-2002).

The Barcelona daily, La Vanguardia, gave greater coverage to the contribution of Rotary International in the eradication of poliomyelitis (La Vanguardia, 27-6-2002, p. 30). Six months after certification, the newspaper used the victory over polio in Europe to intensify its campaign to expose the continuing presence of polio in other parts of the World and to describe the work carried out to achieve its eradication. The newspaper made a call for solidarity in the provision of resources to achieve the worldwide elimination of the disease (La Vanguardia, 22-12-2002).

In the years since the eradication of poliomyelitis in Europe, the Spanish press has continued to publish reports of the work that is still being done to achieve the worldwide elimination of the problem, of the difficulties and setbacks that must be overcome, of the reappearance of the disease in some countries where it had been eradicated, and also of the WHO's enduring commitment to this objective.

\section{The Process of Eradication in Spain (1988-2002)}

The Spanish state, within a democratic political and social framework very different to that of the epidemic outbreaks of the mid-twentieth century, had no difficulty in adhering to the strategies developed by the other European countries. The death of the dictator in 1975, the creation of the Ministry of Health and Consumer Affairs in 1977 and the ratification of the Spanish Constitution of 1978 were followed by the General Health Law of 1986 which set out the fundamental guidelines for our health and public health systems ${ }^{34}$ organized around the Autonomous Communities into which Spain was now divided (the new design of the Spanish state established by the Constitution of 1978).

The victory of the Partido Socialista in the 1982 elections brought the consolidation of democracy and the conclusion of the transition that had followed

34 The 1986Law established universal health care cover in Spain. 
the death of Franco. The relationships of the president of the government, Felipe González, with the great statesmen of the European democratic left explain, to a certain extent, the influence of social democracy in the health policies developed in Spain. This approach led Spain to become an irrevocable part of the western world. The most significant event took place in 1985 when Spain joined the European Union; a transcendental step in the country's economic development, which produced an increase in social and research spending, which in turn led to the establishment of a welfare state.

It is important to underline the fact that the two fundamental aspects of the health reform (decentralization and the implementation of a primary health care system)were the result of a determination to reinforce Public Health. In the early years of the government of the conservative Partido Popular, following their victory in 1996, there were no substantial changes in health policy.

In this context, between 1988 (the last reported case of polio in Spain) and 2002, the country, together with the other members of the European region of the WHO, enjoyed appropriate conditions for the eradication of poliomyelitis. However, the process was not devoid of problems and although in 1988 polio was a controlled disease; the certification of eradication was delayed until the results were guaranteed in $2002^{35}$.

\section{The Figures}

The situation in Spain in terms of the number of notified cases of poliomyelitis in 1988 showed a sharp fall in the number of affected people since the introduction of the first mass anti-polio immunization campaign of 1963-1964 with oral vaccine. From the 1500 cases per year in 1950 and the more than 2000 cases in 1959, the figure had dropped to below 100 in 1964 and $1965^{36}$. However, this decrease was not maintained in the subsequent years. The process was one of problems and setbacks which, while disclosed by the health professionals, were not always sufficiently divulged by the health authorities ${ }^{37}$. As we shown in another paper, in which we analyzed the annual polio morbidity distribution in all provincial capitals and provinces in Spain ${ }^{38}$ between 1965and 1975, this disease persisted as a public

35 Information done by Ferrán Martínez-Navarro and Andreu Segura.

36 María-José Báguena; María-Isabel Porras; Rosa Ballester, "Poliomyelitis in rural and urban Spain: epidemiological trends, social and scientific responses", in A. Andresen; J. L. Barona and S. Cherry, eds, Making a new Countryside (Frankfurt, 2010), pp. 113-132.

37 Enrique Nájera et al., "Análisis epidemiológico de la situación actual de la poliomielitis en España”, Revista de Sanidad e Higiene Pública, 49 (1975), 953-1025.

38 The only breakdown possible of the morbidity data provided by the Instituto Nacional de Estadistica (INE). 
health problem throughout this ten-year period ${ }^{39}$. Indeed the situation deteriorated; in 1965 there were ten provincial capitals with above zero morbidity, in 1975 there were twenty. Apart from Madrid and Barcelona (the two Spanish cities with the highest population), Almería was the provincial capital with the highest rates. Our study has also confirmed that the problem was most severe in the south of Spain, both in the provincial capitals and the rest of the provincial areas, although there were some differences between the two. Indeed, the capitals with the most years among the five reporting the highest rates of morbidity were: Almería (7 years), Huelva (5 years), Granada (4 years), Badajoz, Córdoba, Las Palmas and Santander (3 years). The provinces that recorded the highest rate in the most number of years were: Las Palmas (7 years), Cádiz and Sevilla (6 years), Almería (5 years), Granada and Barcelona (4 years) and Murcia (3 years). We see that Almería (7 and 5 years), Las Palmas (3 and 7 years) and Granada ( 4 and 4 years), which belong to the south of the peninsula and the southern Canary Island archipelago, coincide in both sections and have the highest polio morbidity rates. The situation was more serious in Andalucía than in other autonomous communities ${ }^{40}$, especially in the provinces of Seville - as the ABC and El País newspapers of the late 1970s and early 1980s reported - and Almería ${ }^{41}$.

Leaving aside for the moment the reasons behind this situation, which differs from that of other European countries at the time of the death of Franco, we must ask ourselves to what extent the situation would change in the following years. An analysis of the development of the higher and lower morbidity rates in the provincial capitals (table 1) and in the rest of the province (table 2) between 1976 and 1988 shows that polio remained a problem in most southern capitals and provinces, except in Seville, where in 1972, the authorities had implemented the First Pilot Program of Home Vaccination which, in the six years that it lasted,

39 María-Isabel Porras; María-José Báguena, "El conocimiento sobre la realidad de las campañas de vacunación contra la polio, su cobertura, su seguimiento, la percepción de la población sobre su eficacia y/o peligrosidad y el reflejo en la prensa diaria (1963-1975)", at the Conference: Politica, salud y enfermedad en España: entre el desarrollismo y la transición. Alicante, December 12-13, 2013.

40 Valenciano, Mezquita, Pérez Gallardo and Gabriel y Galán showed in 1969 the unequal distribution of the poliomyelitis morbidity rates between the North and the South of Spain: Luis Valenciano; Manuel Mezquita; Florencio Pérez Gallardo; Jesús Gabriel y Galán, "Estudio epidemiológico y virológico de la poliomielitis en España durante el quinquenio 19641968", Revista de Sanidad e Higiene Pública, 43 (1969), 517-564.

41 Porras and Báguena has recently confirmed, thissituation as well as the high morbidity rates of Almería:María-Isabel Porras; María-José Báguena, "El conocimiento sobre la realidad de las campañas de vacunación contra la polio, su cobertura, su seguimiento, la percepción de la población sobre su eficacia y/o peligrosidad y el reflejo en la prensa diaria (1963-1975)", in Conference: Política, salud y enfermedad en España: entre el desarrollismo y la transición. Alicante, December 12-13, 2013. 
achieved a significant reduction in the number of cases; in 1977 not a single case was reported in the province of Sevilla ${ }^{42}$.

Table 1. Polio morbidity rates (per 100,000 inhabitants) by capital (1976-1988)

\begin{tabular}{|c|c|c|c|c|c|c|c|c|c|c|c|c|c|}
\hline Capital & $\begin{array}{l}197 \\
6 \\
\end{array}$ & $\begin{array}{l}197 \\
7 \\
\end{array}$ & 1978 & $\begin{array}{l}197 \\
9 \\
\end{array}$ & $\begin{array}{l}198 \\
0 \\
\end{array}$ & $\begin{array}{l}198 \\
1 \\
\end{array}$ & $\begin{array}{l}198 \\
2 \\
\end{array}$ & $\begin{array}{l}198 \\
3 \\
\end{array}$ & $\begin{array}{l}198 \\
4 \\
\end{array}$ & $\begin{array}{l}198 \\
5 \\
\end{array}$ & $\begin{array}{l}198 \\
6 \\
\end{array}$ & $\begin{array}{l}198 \\
7 \\
\end{array}$ & $\begin{array}{l}198 \\
8 \\
\end{array}$ \\
\hline Almería & - & - & 19.21 & - & - & - & ND & ND & - & - & ND & ND & ND \\
\hline Bilbao & - & - & - & - & - & 0.23 & ND & ND & - & - & ND & ND & ND \\
\hline Cádiz & 1.47 & 0.73 & 0.73 & - & - & - & ND & ND & - & - & ND & ND & ND \\
\hline Coruña, La & - & - & - & - & - & - & ND & ND & - & - & ND & ND & ND \\
\hline Granada & 1.57 & 0.52 & 2.62 & 1.05 & - & - & ND & ND & - & - & ND & ND & ND \\
\hline Huelva & 1.03 & - & - & - & - & 1.03 & ND & ND & - & - & ND & ND & ND \\
\hline Lugo & - & - & - & - & - & - & ND & ND & - & - & ND & ND & ND \\
\hline Málaga & 0.53 & - & 0.80 & - & - & - & ND & ND & - & - & ND & ND & ND \\
\hline Oviedo & - & - & - & - & - & 0.52 & ND & ND & - & - & ND & ND & ND \\
\hline $\begin{array}{l}\text { Palmas de G. C., } \\
\text { Las }\end{array}$ & - & - & 0.34 & 0.34 & - & - & ND & ND & - & 0.27 & ND & ND & ND \\
\hline Pamplona & - & - & - & - & 0.54 & - & ND & ND & - & - & ND & ND & ND \\
\hline Pontevedra & - & - & - & - & - & - & ND & ND & - & - & ND & ND & ND \\
\hline San Sebastián & 0.60 & - & - & - & - & - & ND & ND & - & - & ND & ND & ND \\
\hline Santander & - & - & - & - & - & - & ND & ND & - & - & ND & ND & ND \\
\hline Sevilla & 0.18 & - & 0.18 & - & - & - & ND & ND & - & - & ND & ND & ND \\
\hline Vitoria & - & - & - & - & - & - & ND & ND & - & - & ND & ND & ND \\
\hline
\end{tabular}

Source: Instituto Nacional de Estadistica (INE). By the authors. Southern capitals in bold letters (ND: no data).

Although, in the following years, the morbidity rate did not remain at zero, it was still better than in Almería, Granada or Cádiz (tables 1 and 2). The examples that we have chosen from the North of Spain show that in those regions, polio had ceased to be a problem in the years of the so-called "transición democráctica". The last two cases in Spain were reported in 1988; one imported from Mauritania and the other post-vacunal ${ }^{43}$.

Without seeking to provide a comprehensive analysis, but rather to clarify what follows, we should outline the main factors that appear to explain the persistence of polio in Spain: a failure to achieve total immunization of children under seven in the 1963-64 national campaign with oral vaccine and a similar failure with children under 12 months in subsequent years; the fact that two doses proved insufficient to achieve complete immunity among the population vaccinated; the particular importance of the type 1 virus (linked to the paralytic form of the disease) in Spain; the lack of resources and the shortcomings in health management in the vaccination programs; bureaucratic hindrance, as revealed in the case of Seville;

42 M. Jiménez, "La polio no ha desaparecido", $A B C, 05 / 06 / 1981$, p. 28.

43 Instituto de Salud Carlos III, "Plan de actuaciones necesarias para la consecución del Certificado de Erradicación de la Poliomielitis”, Boletín epidemiológico semanal, 5(13) (1997), 126-128, p. 126. 
restrictions in the support role of themass media due to lack of public funding from the Francoist state, which after 1965 led to the virtual disappearance of polio from the pages of those daily newspapers we have consulted; breakdowns in the cold chain, a concern of Sabin ${ }^{44}$ which appears to have been confirmed by the national study performed in 1988-89 ${ }^{45}$; and the lack of urgency in the organization of the first competent laboratory of virology for the confirmation of polio diagnoses and even more so in establishing a network of specialized laboratories ${ }^{46}$.

Table 2. Morbidity rates (per 100,000 inhabitants) for polio in the rest of the province (1976-1988)

\begin{tabular}{llllllllllllll}
\hline $\begin{array}{l}\text { Resto } \\
\text { provincia }\end{array}$ & 1976 & 1977 & 1978 & 1979 & 1980 & 1981 & $1982^{*}$ & $1983^{*}$ & $\begin{array}{l}1984 \\
* *\end{array}$ & 1985 & $1986^{*}$ & $1987^{*}$ & $1988^{*}$ \\
\hline Álava & - & - & - & - & - & - & - & - & ND & - & - & - & - \\
Almería & - & - & 3.83 & - & - & - & 0.37 & 1.13 & ND & 0.37 & - & 1.13 & 1.13 \\
Asturias & - & 0.11 & - & - & - & - & - & - & ND & - & - & - & - \\
Cádiz & 0.13 & 0.66 & 0.13 & - & - & - & - & 0.11 & ND & - & - & - & - \\
Cantabria & 0.31 & - & - & 0.31 & - & - & - & - & ND & - & - & - & - \\
Coruña, La & - & - & - & - & - & - & 0.23 & - & ND & - & - & - & - \\
Granada & 0.36 & 0.55 & 0.92 & 0.73 & - & - & - & 0.20 & ND & - & - & - & - \\
Guipúzcoa & 0.21 & 0.21 & - & - & - & - & - & - & ND & - & - & - & - \\
Huelva & - & - & 0.66 & 0.33 & - & - & - & 0.69 & ND & - & - & - & - \\
Lugo & - & - & - & - & - & - & - & - & ND & - & - & - & - \\
Málaga & 0.40 & 0.20 & 0.60 & - & 0.18 & - & - & 0.18 & ND & - & - & 0.37 & - \\
Navarra & - & - & - & - & - & - & - & - & ND & - & - & - & - \\
Palmas, Las & 1.36 & 0.34 & 0.34 & - & - & - & 0.25 & 0.25 & ND & - & - & - & - \\
Pontevedra & 0.57 & - & 0.28 & - & - & 0.12 & - & - & ND & - & - & - & - \\
Sevilla & - & - & - & 0.45 & 0.12 & 0.12 & - & 0.12 & ND & - & - & - & - \\
Vizcaya & - & 0.15 & - & - & - & 0.26 & - & - & ND & - & - & - & - \\
\hline Source & & & & & & & &
\end{tabular}

Source: Instituto Nacional de Estadística (INE). By the authors. (ND: no data)

*There is no breakdown of the data for capitals for 1982, 1983, 1986, 1987 and 1988, and therefore it is not possible to know if the data for cases per province include cases in provincial capitals.

**According to national morbidity data for 1984 , there was one case of polio. As there were no cases in provincial capitals, it must have occurred in one of the provinces. However we do not have a breakdown per province.

44 Albert Sabin expressed his concern in a letter to Florencio Pérez Gallardo: http://hdl.handle.net/2374.uc/670052. The personal files of Albert Sabin are available at: http://digitalprojects.libraries.uc.edu/sabin/

45 José Tuells et al., "El primer ensayo de campo sobre cadena de frío vacunal en España (Alicante, 1986-88)", Vacunas, 2 (2009), 42-48; José Tuells, "El frágil inicio de la cadena de frío vacunal en España", Gaceta Sanitaria, 4 (4) (2010), 354-357.

46 María-Isabel Porras; María-José Báguena, "El conocimiento sobre la realidad de las campañas de vacunación contra la polio, su cobertura, su seguimiento, la percepción de la población sobre su eficacia y/o peligrosidad y el reflejo en la prensa diaria (1963-1975)", in Conference: Politica, salud y enfermedad en España: entre el desarrollismo y la transición. Alicante, December 12-13, 2013. 
Regarding this last factor, some changes did take place in the early years of the "transición democrática", which took advantage of some of the improvements achieved during the dictatorship with the support of international organizations (WHO, Rockefeller Foundation). Rafael Nájera took over the leadership of the National Centre of Microbiology, Virology and Immunology of the Carlos III Institute of Health. The first goal of his team, with an excellent scientific tradition in spite of the political circumstances of Francoism ${ }^{47}$, was the eradication of polio through the introduction of the criteria of the WHO classification and characterization studies of polioviruses ${ }^{48}$. The anti-polio vaccination rate had passed the $80 \%$ mark and subsequently reached $91 \%$ in 1996 (this was even thought to be below the actual figure as it did not include immunizations performed outside the public sector $)^{49}$. Furthermore, as we shall describe below, with the formal application of a specific programme for Spain, the authorities began use of the CMBD database (Conjunto Mínimo Básico de Datos - Basic Minimum Data Set), introduced into the Spanish Health System in 1987, as a complementary source of data to follow up cases of acute flaccid paralysis (AFP) ${ }^{50}$. In 1995, the number of cases of AFP reported by the CMBD in the Spanish state among the under-15s was 66, a rate of between 1.2 and 1.6 cases per 100,000 inhabitants. None of these cases finally proved to be polio.

\section{Implementation of the Poliomyelitis Eradication Plan in Spain}

The report drafted at the first meeting of the Global Commission for the Certification of the Eradication of Poliomyelitis (GCC), mentioned above, was swiftly transmitted by the Ministry of Health and Consumer Affairs to the Autonomous Communities, which now held political responsibility for health. It is important to point out that this was the situation of a third of the Spanish Autonomous Communities in 1996. The rest of them had only political responsibility for public health and get for medical care some years later. The Autonomous Communities were asked to study

47 María-Isabel Porras; Mariano Ayarzagüena; Jaime de las Heras; María-José Báguena, eds., El drama de la polio. Un problema social y familiar en la España franquista (Madrid, 2013).

48 Rafael Nájera, "La última fase: la eliminación", Revista española de Salud Pública, 87 (2013), 461-469.

49 Instituto de Salud Carlos III, "Plan de actuaciones necesarias para la consecución del Certificado de Erradicación de la Poliomielitis", Boletín epidemiológico semanal, 5 (13) (1997), 126-128, p. 126.

50 The Flaccid Paralysis Syndrome (AFP) is characterized by a rapid muscular weakening in the lower limbs and, on occasions, in the respiratory muscles. It is essentially a disease of infancy. Its interest for polio surveillance is that this syndrome can be caused by polio. 
the viability of the implementation of a Poliomyelitis Eradication Plan in Spain ${ }^{51}$, and an analysis was made of the strategies recommended by the WHO for the eradication of poliomyelitis in the European Region, based on the conclusions of the first meeting of the European Regional Commission for the Certification of the Eradication of Poliomyelitis ${ }^{52}$.

The organization of the Plan had a central structure, in which the Autonomous Communities participated in epidemiological surveillance and the monitoring of hypothetical cases. Nonetheless, poliomyelitis came to be seen as an increasingly distant threat. The Autonomous Communities and the Ministry maintained both technical relations (through the Epidemiological Surveillance Groups) and political contacts (through the Public Health Commissions).The highest level of political representation within the state of the autonomies on this and other questions was, and still is, the Consejo Interterritorial del Sistema Nacional de Salud (Interterritorial Council of the National Health System).

The first decision adopted at state level was the constitution, in 1996, of a Working Group of the Poliomyelitis Eradication Plan (GT-PEP) made up of representatives of the Ministry of Health and Consumer Affairs (General Board of Public Health, the Carlos III Health Institute and the National Institute of Health) as well as representatives of scientific societies (Epidemiology, Neurology, Pediatrics and Virology). Representatives of the Poliomyelitis Eradication Plan in the Autonomous Communities were subsequently appointed and a coordination meeting was held between them and the GT-PEP which approved a timetable for the process of certification of the eradication of poliomyelitis in $\operatorname{Spain}^{53}$. The schedule covered the period between 1996 and 2000, and set milestones ranging from the introduction of a system of epidemiological surveillance of flaccid paralysis to the presentation of the final report of the GT-PEP to the National Committee in 2000.

The creation of a National Committee of Experts for the attainment of the Certificate of Eradication of Poliomyelitis in Spain, in1997, represented the last of the bases required for the Plan to reach its goal ${ }^{54}$. Recourse to experts was not a

51 Rafael Nájera, "Intentos y dificultades en la erradicación de la poliomielitis", in R. Nájera, coord., Erradicación y control de las enfermedades producidas por virus (Madrid, 2012), pp. 433-464.

52 Report of the 1st meeting of the Global Commission for the certification of the Eradication of Poliomyelitis (Geneva, 1995).WU WHO/EPI/GEN95.6 document WHO.

53 Instituto de Salud Carlos III, "Plan de actuaciones necesarias para la consecución del Certificado de Erradicación de la Poliomielitis",Boletín epidemiológico semanal, 5(13) (1997), 126128.

54 Ministerio de Sanidad y Consumo. Instituto de Salud Carlos III. Plan de actuaciones necesarias para la consecución del certificado de erradicación de la poliomielitis. (Madrid, 1988). Ferrán Martínez -Navarro, 'La Comisión Nacional para la certificación de la erradicación de la 
compulsory criterion of the $\mathrm{WHO}$, although it was an important recommendation and a feature of the organization's working methods, as we have described in other studies $^{55}$. This purely technical level, together with the political and administrative structures, was important from the point of view of the programme because among the recommendations of the WHO was the suggestion that this type of committee should include eminent professionals who were not directly involved in the measures to eradicate poliomyelitis. We should add that a review of the names of those who made up this Committee ${ }^{56}$, shows that the experts, whose chairman was Ferrán Martínez Navarro - a highly experienced epidemiologist and renowned professional who had attended some of the European meetings mentioned aboveprovided guarantees that things should be done according to the guidelines. One of the spokespersons, the virologist and epidemiologist Rafael Nájera Morrondo, cited above, had been a member of the Florencio Pérez Gallardo's $s^{57}$ working group of the National School of Health during the implementation of the first mass immunization campaigns.

The results achieved in the preliminary work led to the adoption of a series of decisions which took shape in a Proposal setting out the required measures to obtain the certificate of eradication of poliomyelitis in Spain. In brief:

- to set up an efficient service to monitor acute flaccid paralysis;

- to achieve and maintain high levels of immunization cover;

poliomielitis" in Juan A. Rodríguez-Sánchez, Jesús Seco-Calvo, eds. La poliomielitis en Castilla y León. Vacunación, erradicación y efectos tardios (León, 2015, in press).

55 María-Isabel Porras; Rosa Ballester; María-José Báguena; Jaime delas Heras, "La Asociación Europea frente a la Polio y los programas europeos de vacunación", Dynamis, 32(2) (2012), 287-310; Rosa Ballester; María-Isabel Porras; María-José Báguena, "La respuesta de las agencias internacionales (NFIP, OMS, AEP) al problema de la poliomielitis" in M.I. Porras; M. Ayarzagüena; J. de las Heras; M.J.Báguena, eds., El dramade la polio. Un problema social y familiar en la España franquista (Madrid, 2013); María-Isabel Porras; María-José Báguena; Rosa Ballester, "Spain and the international scientific conferences on polio, 1940s-1960s",Dynamis, 30 (2010), 91-118.

56 The composition was the following: President: Ferrán Martínez-Navarro, Chief of the Epidemiological Surveillance Area of the Instituto de Salud Carlos III of the Ministry of Health. Spokespersons: Two professors of Pediatrícs and Neurology (Manuel Moya Benavent and Alberto Portera Sánchez), the President of the Health Advisory Council (José-María Segovia de Arana), the Chief of the Retrovirus Area of the National Center of Fundamental Biology of Majadahonda (Rafael Nájera-Morrondo), the Chief of the Biological Products Area of the IS Carlos III, Francisco Salmerón-García and two technicians from INSALUD and the National School of Health.

57 Florencio Pérez Gallardo was a prominent Spanish scientist who took part of the European Association against Poliomyelitis on behalf of the World Health Organisation. MaríaIsabel Porras; María-José Báguena; Rosa Ballester, "Spain and the scientific conferences on polio, 1940s-1960s", Dynamis, 30 (2010), 113-119. 
- to implement a system of environmental surveillance to detect wild polioviruses in individual and environmental samples and

- to carry out a seroepidemiological study to assess the immunity of the population.

The first three objectives responded point by point to the instructions of the WHO. The fourth was a supplementary measure which we have described in other studies $^{58}$ and which the Committee was able to include in the Project following the introduction in 1996 of a national seroepidemiological macro study, which was carried out in the Autonomous Communities and in the towns of Ceuta and Melilla in order to determine the serological profile of the population between 2 and 40 years of age in relation to such specific infectious agents as polioviruses 1, 2 and $3^{59}$.

As we can see, the implementation of these systems in the National Epidemiological Surveillance Network were key to the work programme and of the specific measures of the network, which ranged from how to detect suspected cases to the arrangements for the laboratory which would deal with the stool samples and the most suitable laboratory techniques for the processing of suspected cases of acute flaccid paralysis. The weekly dispatch of this information to the European Regional Office of the WHO and the drafting of annual reports signalled the path towards the finishing line.

Nevertheless, from the outset, the monitoring system for acute flaccid paralysis in Spain suffered from low sensitivity and low reporting. The level of notified incidence in Spain was below the 2000 WHO estimate ${ }^{60}$ of one case per 100,000 inhabitants. The reasons for this appear to be the absence of polio cases and the association between AFP and other conditions such as Guillain-Barré syndrome. Indeed, an active search for AFP in the National Minimum Dataset (a national collection of public and private hospital discharge information, including coded clinical data for inpatients and day patients) does provide a rate similar to the figure estimated by the WHO in most autonomous communities. This situation, and the

58 María-Isabel Porras; Rosa Ballester, "El significado histórico de las encuestas de seroprevalencia como tecnología de laboratorio aplicada a las campañas de inmunización. El caso de la poliomielitis en España”, Asclepio, 61(1) (2009), 55-80.

59 Instituto de Salud Carlos III, "Plan de actuaciones necesarias para la consecución del Certificado de Erradicación de la Poliomielitis”, Boletín epidemiológico semanal, 5(13) (1997), 128.

60 Isabel Pachón del Amo; C. Sanz Ortiz; B. Merino Merino, "Sistema de vigilancia de parálisis flácida aguda (PFA): descripción de los primeros casos notificados", Boletín epidemiológico semanal, 5(31) (1997), 289-292. Isabel Pachón del Amo; M. C. Sanz Ortiz, "Certificación de la erradicación de la poliomielitis. Sistema de vigilancia de parálisis flácida aguda”, Boletín epidemiológico semanal, 7(18) (1999), 189-192. Isabel Pachón del Amo; M. C. Sanz Ortiz, "Certificación de la erradicación de la poliomielitis. Sistema de Vigilancia de Parálisis Flácida Aguda. Año 2000”, Boletín epidemiológico semanal, 9(8) (2001), 77-81. 
fact that other western European countries (France and Great Britain) have ceased surveillance and instead have opted for environmental monitoring, have led the epidemiologist Ferrán Martínez Navarro to put forward a proposal to follow the example of these countries and to reinforce Spain's response capability in the eventuality of imported cases of polio. ${ }^{61}$.

\section{Concluding Remarks}

Throughout the paper we have shown how the programme for the eradication of polio in Spain was organized on the basis of the decision of the WHO in 1988. Although morbidity had already been reduced by that time, following the great efforts made during the 1960s, the measures taken to achieve certification contributed to the modernization of our system and the establishment of a national epidemiological surveillance network for polio which might be transferable to other infectious diseases. Indeed, polio vaccination represented the starting point for the establishment of vaccination calendars in Spain from 1975 onwards.

The results of the case study allow us to delve into the process by which an international health programme was implemented at a local level, its positive aspects and the difficulties that arose.

Rosa Ballester is professor of History of Science at the Department of Public Health and History of Science, Miguel Hernández University, Spain.

Maria-Isabel Porras is professor of History of Science at the Medical Faculty of Ciudad Real, University of Castilla-La Mancha, Spain.

Maria José Baguena is professor of History of Science at the Institute for the History of Medicine and Science, University of Valencia, Spain

61 Ferrán Martínez-Navarro, “La Comisión Nacional para la certificación de la erradicación de la poliomielitis” in Juan A. Rodríguez-Sánchez, Jesús Seco-Calvo, eds. La poliomielitis en Castilla y León. Vacunación, erradicación y efectos tardios (León, 2015, in press). 


\section{References}

Association Européenne contre la Poliomyélite, IV Symposium, Bologna, 20-22 September 1956. (Bruxelles, 1957).

Association Européenne contre la Poliomyélite, VII Symposium. Oxford, 17-20 September1961. (Bruxelles, 1962).

Aylward, Bruce, Harry F. Hull; Stephen L. Cochi et al., "Disease eradication as a public health strategy: a case study of poliomyelitis eradication," Bulletin of the World Health Organization 78:3 (2000), 285-297.

Báguena, María-José, Porras, María-Isabel, Ballester, Rosa, "Poliomyelitis in rural and urban Spain: epidemiological trends, social and scientific responses," pp. 113-132 in A. Andresen, J. L. Barona and S. Cherry, eds., Making a new Countryside, (Frankfurt, 2010).

Ballester, Rosa, María-Isabel Porras, "El significado histórico de las encuestas de seroprevalencia como tecnología de laboratorio aplicada a las campañas de inmunización. El caso de la poliomielitis en España," Asclepio 61(1) (2009), 55-80.

Ballester, Rosa, María-Isabel Porras; María-José Báguena, "La respuesta de las agencias internacionales (NFIP, OMS, AEP) al problema de la poliomielitis"pp.73-93 in M.I. Porras; M. Ayarzagüena; J. de las Heras; M.J. Báguena, eds, El drama de la polio. Un problema social y familiar en la España franquista. (Madrid, 2013).

Bazin, Hervé The Eradication of Smallpox. (San Diego, 2000).

Brown, Theodore M.; Marcos Cueto, Elisabeth Fee. Historia, salud y globalización. (Lima, 2013).

"Certification of poliomyelitis eradication: European Region," Morbidity and Mortality Weekly Report 51 (2002), 572-574.

Chin, James "Can paralytic poliomyelitis be eliminated?," Clinical Infectious Diseases 6 (Suppl. 2) (1984), S581-S585.

Cueto, Marcos The value of health. A history of the Pan American Health Organization. (Washington, 2007).

De Quadros, Ciro A., "The whole is greater: How polio was eradicated from the Western Hemisphere," pp. 54-69 in Daniel Perlman and Ananya Roy, eds, The Practice of International Health. A case-based orientation. (New York, 2009).

Fenner, Frank "The eradication of infectious diseases," South African Medical Journal 66 (suppl.) (1986), 35-39.

Fenner, Frank, Donald Henderson. Isao Arita, Zdneck Jezek, Ivan Danilovich Ladnyi, Smallpox and its Eradication. (Geneva, 1988). 
Henderson, Donald, "Smallpox eradication: a victory against the Cold War," World Health Forum 19 (1998), 115-121.

Hinman, Alan R, William H. Foege, Ciro A. de Quadros, Peter A. Patriarca, Walter A. Orenstein and Edward W. Brink, "The case for global eradication of poliomyelitis," Bulletin of the World Health Organization 65 (1987), 839.

Horaud, Florian, "Viral Vaccines and Cell Substrate: A 'Historical' Debate,"pp. 151-154 in S.A. Plotkin, ed., History of Vaccine Development. New York, 2011. Hortsmann, Dorothy M., "Preface," Reviews of Infectious Diseases, 6 (Suppl. 2) (1984), S301.

Instituto de Salud Carlos III, "Plan de actuaciones necesarias para la consecución del Certificado de Erradicación de la Poliomielitis", Boletín epidemiológico semanal 5:13 (1997), 126-128.

Jiménez, M., "La polio no ha desaparecido", $A B C, 05 / 06 / 1981$, p. 28.

Katz, Samuel L., Catherine M. Wilfert and Frederick C. Robbins, "The Role of Tissue Culture in Vaccine Development," pp. 145-148 in S.A. Plotkin, ed., History of Vaccine Development. (New York, 2011).

Limia-Sánchez, Aurora, "La erradicación de la poliomielitis en la Región Europea de la Organización Mundial de la Salud", Revista Española de Salud pública 87 (2013), 507-516.

Martínez-Navarro, Ferrán, "La Comisión Nacional para la certificación de la erradicación de la poliomielitis" in Juan A. Rodríguez-Sánchez, Jesús SecoCalvo, eds. La poliomielitis en Castilla y León. Vacunación, erradicación y efectos tardios. (León, 2015 (in press)).

Ministerio de Sanidad y Consumo. Instituto de Salud Carlos III. Plan de actuaciones necesarias para la consecución del certificado de erradicación de la poliomielitis. (Madrid, 1988).

Mosquera, Miguel, Natalia Barón, Rosa Ballester, "El camino hacia la erradicación de la poliomielitis a través de la Organización Panamericana de la Salud", Revista Panamericana de Salud pública 36(3) (2014), 185-192.

Nájera, Enrique, Ángel Llácer, Luis Valenciano, E. Salmerón, Ferrán MartínezNavarro, Manuel Mezquita, Florencio Pérez-Gallardo, "Análisis epidemiológico de la situación actual de la poliomielitis en España," Revista de Sanidad e Higiene Pública 49 (1975), 953-1025.

Nájera, Rafael, "La última fase: la eliminación," Revista española de Salud Pública 87 (2013), 461-469.

Nájera, Rafael, "Intentos y dificultades en la erradicación de la poliomielitis", pp. 433-464 in R. Nájera, coord., Erradicación y control de las enfermedades producidas por virus. (Madrid, 2012). 
Pachón del Amo, Isabel, C. Sanz-Ortiz and B. Merino-Merino, "Sistema de vigilancia de parálisis flácida aguda (PFA): descripción de los primeros casos notificados," Boletín epidemiológico semanal 5(31) (1997), 289-292.

Pachón del Amo, Isabel and M. C. Sanz-Ortiz, "Certificación de la erradicación de la poliomielitis. Sistema de vigilancia de parálisis flácida aguda," Boletín epidemiológico semanal 7(18) (1999), 189-192.

Pachón del Amo, Isabel and M. C. Sanz Ortiz, "Certificación de la erradicación de la poliomielitis. Sistema de Vigilancia de Parálisis Flácida Aguda. Año 2000," Boletin epidemiológico semanal, 9(8) (2001), 77-81.

Poliomyelitis, Papers and Discussions presented at the Third International Poliomyelitis Conference. (Philadelphia, 1955).

Poliomyelitis, Papers and Discussions presented at the Fourth International Poliomyelitis Conference. (Philadelphia, 1958).

Poliomyelitis, Papers and Discussions presented at the Fifth International Poliomyelitis Conference. (Philadelphia, 1961).

Porras, María-Isabel, Mariano Ayarzagüena, Jaime de las Heras and María-José Báguena, eds, El drama de la polio. Un problema social y familiar en la España franquista. (Madrid, 2013).

Porras, María-Isabel and María-José Báguena, "El conocimiento sobre la realidad de las campañas de vacunación contra la polio, su cobertura, su seguimiento, la percepción de la población sobre su eficacia y/o peligrosidad y el reflejo en la prensa diaria (1963-1975)," in Conference: Politica, salud y enfermedad en España: entre el desarrollismo y la transición. Alicante, December 12-13. (Alicante, 2015 (in press)).

Porras,María-Isabel, María-José Báguena and Rosa Ballester, "Spain and the scientific conferences on polio, 1940s-1960s," Dynamis 30 (2010), 91-118.

Porras María-Isabel, Rosa Ballester, María-José Báguena and Jaime de las Heras, "La Asociación Europea contra la Poliomielitis y los programas europeos de vacunación”, Dynamis 32(2) (2012), 287-310.

Report of the 1st meeting of the Global Commission for the certification of the Eradication of Poliomyelitis. (Geneva, 1995).

Seytre, Bernard and Mary Shaffer. Histoire de la poliomyélite. (Paris, 2004).

Smallman-Raynor, Matthew R, Andrew D. Cliff, Barry Trevelyan, Clive Nettleton and Sam Sneddon, A world geography. Poliomyelitis. Emergence to eradication. (Oxford, 2006).

Smith Joseph, Rose Leke, Anthony Adams and Rudolph H. Tangermann, "Certification of polio eradication: process and lessons learned," Bulletin World Health Organization 82(1) (2004), 24-29.

Tuells, José, "El primer ensayo de campo sobre cadena de frío vacunal en España (Alicante, 1986-88)," Vacunas 2 (2009), 42-48. 
Tuells, José "El frágil inicio de la cadena de frío vacunal en España," Gaceta Sanitaria 4(4) (2010), 354-357.

Valenciano, Luis, Manuel Mezquita, Florencio Pérez Gallardo and Jesús Gabriel y Galán, "Estudio epidemiológico y virológico de la poliomielitis en España durante el quinquenio 1964-1968," Revista de Sanidad e Higiene Pública, 43 (1969), 517-564.

World Health Organization. Report of the first meeting of the European Regional Commission for the certification of polio eradication. Paris, 7-8 march 1996. (Geneva, 1996).

World Health Organization. The first ten years of the World Health Organization. Geneva, 1958. World Health Organization. The second ten years of the World Health Organization from 1958 to 1967. (Geneva, 1968).

World Health Organization. Certification of Poliomyelitis Eradication in the European Region. Report on a WHO Meeting. Vienna, 16-17 December 1997. (Copenhagen, 1998).

World Health Organization. The Third ten years of the World Health Organization, 1968-1977. (Geneva, 2008).

World Health Organization. The Fourth ten years of the World Health Organization, 1978-1987. (Geneva, 2011).

\section{Acknowledgements}

This work has been carried out within Projects No HAR2012-39655-C04-01 and HAR2012-39655-C04-02of the Spanish Ministry of Innovation, Economy and Competitiveness (MINECO). A preliminary version of this paper has been presented on the Tercer Congreso Internacional de Humanidades Médicas (São Paulo, Brazil, March 15-16, 2013). 